\title{
The Relationship between Special Needs Education and Socio- Economic Development of People with Disabilities in Huye District
}

\author{
Jean Bosco Kabanda ${ }^{1}$, Hesbon O Andala ${ }^{2}$ and Jean Paul \\ Harerimana $^{3}$ \\ ${ }^{1,2,3}$ School of Education, Mount Kenya University, \\ Kigali, Rwanda
}

\begin{abstract}
The main objective of this study was to establish the relationship between special needs education and socio- economic development of people disabilities in Huye district. As for methodology the research employed both descriptive and explanatory design. The sample size to be selected was 138 out of 210 disabled people in schools that provide special needs education in Huye district. A questionnaire was used as the main tool for data collection and the data were analyzed using SPSS 21.0 software and interpretation was based upon the findings. This research used probability sampling technique in which the researcher used stratified random sampling technique where the decided population was grouped into strata for the disabled people in Huye district. The researcher used proportionate method in order to get representative of each stratum. It was revealed that there is very low positive correlation between all indicators of special needs education but the significance relationship was found between mainstreaming and socio-economic development of disabled people considering $(\mathrm{r})=.181 *, \mathrm{P}=.033)$. Stakeholders in social-economic development and other partners are recommended to put more efforts all programs that are intended to help disabled people to be more self-sufficient in terms of wellbeing.

Keywords: special needs, special needs education, socio- economic development and people with disabilities
\end{abstract}

\section{Introduction}

According to Kizito,(2006) in many developing countries of the world, people face socio-economic problems. In Africa for example; these problems are often due to ethnic conflicts,political turmoil, natural and other disasters, which cause disturbance that affects human development. There are over 500 million of persons with disability worldwide which presents about $10 \%$ of the global population. In certain developing countries nearly $20 \%$ of the general population is in some way disabled; if the impact of human development is not taken into account, $50 \%$ of the population would be affected (World Bank Report, 1991).

The field of special education has developed relatively recently and unevenly in different parts of the world (Reynolds and Ainscow, 1994). Its development has involved a series of stages during which education systems have explored different ways of responding to children with disabilities and others who experience difficulties in learning. As a result, special education has sometimes been provided as a supplement to general education provision, whereas in other cases it may be totally separate.

Among these are youths and children who require Special Educational adjustments in order to participate in the mainstream education services. This may entail among other provisions, putting in place school and community-based support services, and/or availing adequately accessible educational resources (specialized educational materials and skilled personnel), that render the teaching and learning environment barrier-free and accessible to all learners, especially those with special educational needs (SEN). The policy focuses on education of children with special educational needs (SENs) in Rwandan special and inclusive schools both (private and public) (MINEDUC, 2018).

It has been reiterated through national policy plans that the Government of Rwanda is committed to reducing poverty and improving the well-being of its population, as a means of responding to the Sustainable Development Goals (SDGs), specifically 
goals four, eight, ten, eleven and seventeen, specifically in parts related to education, growth and employment, inequality, accessibility of human settlements, as well as data collection and monitoring. Thus, in support and compliance with the goals, the present Special needs \& inclusive education policy is also guided by the Seven Year Government Program: National Strategy for Transformation (NST1) envisioning economic transformations through a deliberate focus and investment in education of children and youths with Special Educational Needs(MINEDUC, 2018).

Rwanda's commitment to the education of disadvantaged children is well highlighted in the MINEDUC Education Sector Strategic Plan Framework for basic education (ESSP) 2018/19$2023 / 24$ as a cross-cutting issue, which also resonates with article 40 of the National Constitution of 2003 as revised in 2015 article 20 stating that

"Every person has the right to education. The State has the duty to take special measures to facilitate the education of the disadvantaged learners".

The present policy document therefore, is deliberately focused on this category of educationally disadvantaged children and youths (up to 18 years of age), here-referred to as "learners with Special Educational Needs' (SEN), seeking to remove barriers experienced in learning and participation in ordinary school system (MINEDUC, 2018).

There are also new or revised National important documents the previous policy did not put into consideration like the 7YGP/NST1, revised Constitution of the Republic of Rwanda, Integrated child Right policy, Education Sector Strategic Plan (ESSP) 2018/19-2023/24 and the Sustainable Development Goals (SDGs) (MINEDUC, 2018). Against that background this study aims at examining the impact of special education on socioeconomic development of disables people in Rwanda.

But today in Rwanda, especially after genocide of 1994, this issue of education of people with disability has become a major concern for politicians or Educational policy makers but until now few people have done research on this topic. Yet when this category of people is neglected, it can also affect their families as well as the social and economic development of the entire societies. This aroused the researcher's interest to carry out a research on the role of special needs education in improving the socio-economic development of people with disability in Huye District, Rwanda.

\section{Review of Literature}

According to Karangwa (2012) Special needs is observed to any child who is experiencing\# difficulties in learning. He categorized children who

\section{ISSN 2455-6378}

may have special needs in the following categories: Girls, Ethnic minority children with disability, very poor children (orphans, street children), and gifted children (children who extremely clever), and children affected by VIH and AIDS, children with social and emotional problems, genocide survivors. For Heward \&Orlansky, (1992) Children with special education needs include those children with learning and or behavior problems, children with physical disabilities, and children who are instinctual gifted are those whose differences from the norm are large enough to require a special designed instructional program if they are to benefit fully from education.

The concept of inclusion implies that students with disabilities belong to the local school and under the responsibility of the general classroom teachers. The school provides for the needs of all students irrespective of their level of their ability or disability and promotes a sense of "belonging" for all students (Foreman, 2011).

Inclusion requires general education schools to restructure and reorganize their practices and routines to accommodate students with disabilities. Such reorganization of regular education schools is founded on an organizational paradigm (Ainscow, 1999; Clark, et al, 1995; Lipsky, 2003; Villa and Thousand, 1999). This paradigm departs from the medical model that puts the blame on the student rather than the school. According to this paradigm, it is the organization of schools rather than the deficits in students that is responsible for the failure of general education to meet the needs of students

Access to a special education classroom, often called a "self-contained classroom or resource room", is valuable to the student with a disability. Students have the ability to work one-to-one with special education teachers, addressing any need for remediation during the school day. Many researchers, educators and parents have advocated the importance of these classrooms amongst political environments that favor their elimination (Sindelar \& Deno, 1971). Oftentimes mainstreamed students will have certain supports they will bring to the general education classroom.

Proponents of both the philosophy of educational inclusion assert that educating children with disabilities alongside their non-disabled peers fosters understanding and tolerance, better preparing students of all abilities to function in the world beyond school (IDEA, 2001). Children with special needs may face social stigma as a result of being mainstreamed, but also may help them socially develop (Carissa, 2015).

An increasing number of development authors have proposed the term socio-economic development or social development and related understandings to depart from the economics riveted notion of development (Brokensha, 2001; Filgueira, 2001; 
Sen, 1988). In fact, although the concept development is one of the most pressing topics of our times, it has come to mean different things for different people in different situations and in different locations.

Social science literature shows five major trails of meanings ascribed to development: psychological, which represents the unfolding of human personality (Thornton, 2008), philanthropic, the most common in information management/science and related fields, which entails humanitarian or small-scale managerial works in rural or poor areas of developing nations (Subramanian and Jones, 2013), infrastructural, which involves facilities, houses, transportation structures, land, energy/water supply, (Adams and Ties dell, 2012; Perry, 2001), economic, which requires specific statistics, such as GDP, labor, capital, currency, health insurance, (Weil, 2012), and journalistic, which means event, story, fact, account. (The Oxford American Dictionary, 1999)

Weber's conceptualization of social class has been reflected in the three most commonly used indicators of socioeconomic status -education, income and occupation (Grundy and Holt 2001). These three indicators are correlated and possess some degree of overlap in most cases. No single one of the three possesses all of the qualities above mentioned. Grundy and Holt (2001) therefore, suggest the composite use of the three of them. But this might introduce problems of Malnutrition as the three indicators have been found to have high degree of correlation (see appendix 3 for cross tabulations of education and social class). Malnutrition makes it difficult to disentangle the separate influences of the independent variables on the dependent variables (Moffatt, 2013)

Disability can be seen as the condition of being unable to do things that one naturally or normally should be able to effectively do without help from another person (Verbrugge, 1994). It is a multidimensional concept and experience arising from the interactions of health conditions and physical environment (Emerson et al, 2009). It is an ability restricting impairment. The World Health Organization sees disability as an umbrella term that encompasses impairments, activity limitations and participation restrictions (WHO, 2014). WHO defines impairments to be problems in body function or structure; activity limitation to be difficulty encountered by an individual in executing a task or action; it sees participation restriction is a problem experienced by an individual in involvement in life situations.

Disabilities are in many kinds and they affect different functions in a person. These functions may vary from vision, movement, judgment, memory, learning, communicating, hearing, mental health, to social relationships (CDC, 2014). Disability gap is the difference between an individual's capability to complete a particular task and the demand imposed by the task (Verbrugge, 1990). Disability gaps can be reduced or increased by either altering what the task demands or the capability of the individual. If capability is kept constant and the demand is reduced, for example by introducing a machine, which would then demand less effort, the disability gap is reduced. The individual's capability can also be improved, which also reduces the disability gap. By recognizing and implementing change where needed, elderly individuals, even those mildly to moderately disabled, can maintain an active, independent life (Ostir.et al 1999).

Several domains of disability have been proposed; they include physical, cognitive, sensory, emotional and social functioning. Frailty in old age may be associated with one or two of these domains (Guralnik and Simonsick 1993). This study focuses on the physical and cognitive domains of disability. Guralnik and Simonsick (1993) explain that physical and cognitive disabilities have the greatest impact on the overall burden of frailty and disability in the United States. Several studies have also shown that a significant number of adults and children in the UK live with one form of disability or the other (see Breeze and Lang, 2008)

\section{Materials and Methods}

A research design refers to overall strategies and instructions to be followed when addressing the research. Decisions are supposed to be so as to maximize the validity of the eventual results (Mouton, 2009).The researcher employed both descriptive and explanatory design. It was vital to employ explanatory style as indicated by Best (1970) as well as descriptive means as noted by Borg (1988), if the opinions and attitude are to be explicitly represented and generalized to the targeted population.

According to Kakoze, (2008) population refers to groups or categories of human beings, animals and other things that have one or more characteristics in common as the target population of the universe. Richard et al (2006) define the population as any group of people or specific aggregation of elements from the sample, which is selected.

Manheim\&Rich (2002), define a sample as any subgroup of the population, which is identified for analysis.

The population under the study is composed by the physically disabled persons who included males and females of different age groups, sex and educational background among others. This population was drawn from the different household with different characteristics related to Housing incomes and occupational data and the total number was 210 .Data 3.1 below indicates the population under the study in Huye District 
Sample design comprises of two essentials and that is the sample size determination and sampling technique. Sampling technique refers to the procedures that researcher should use to get samples from population. The research employed both descriptive and explanatory research design.

According to Polit \& Beck (2000), the sample size refers to subset of a population selected to participate in a study. To carry out a research, it is necessary to select a sample. In the following lines, the researcher shows the target population and the selected sample.
ISSN 2455-6378

To select a representative sample, a researcher must firs have a sampling frame

A sampling frame can be defined as a list,director or index of cases from which a sample can be selected. Hence to reach the sample size in this study the formula of Yamane was used: $\mathbf{n}=\frac{\mathbf{N}}{1+\mathrm{N}(\mathrm{e})^{2}}, \mathbf{n}=$ $\frac{210}{1+210(0.05)^{2}}=138$

According to that formula $\mathrm{n}=$ Sample size, $\mathrm{N}$ : Population of the study, and $\mathrm{e}=$ Error Terms

Hence the sample size is the following:

Table 3. 1 : Sample size and population of the study

\begin{tabular}{lccc}
\hline Sectors & \multicolumn{3}{c}{ Number of Disabled } \\
\cline { 2 - 4 } & Boys & Girls & Total \\
\cline { 2 - 4 } Tumba & 71 & 59 & 120 \\
Ngoma & 58 & 32 & 90 \\
Total & 129 & 91 & 210 \\
Percentage & 61.5 & 38.6 & $100 \%$ \\
\hline
\end{tabular}

Source: Data from the field, (2020)

This research used probability sampling technique in which the researcher used stratified random sampling technique where the decided population was grouped into strata. The researcher also used proportionate method in order to get representative of each stratum for the participants of the disabled in Huye district.

Data collection is the process by which a research gets information from each selected unit in survey (Ivan, 2003). Carl \&Roger (1991), defines a questionnaire as "' a set question designed to generate the data necessary for accomplishing the objectives of the research project'. They further argue that questionnaire is a formulized schedule for collecting information from responds and in this case the type of questionnaire used were both open-ended and closed-ended Harper and Ralph(1989) to get views of the put forward the advantages of questionnaire method.The advantage is veracity and speed and cost. By veracity-many problems can be studies only by questioning, speed and cost questioning is usual faster for respondents to provide information. However, the questionnaire was addressed to disabled people in this study.
Data collected through questionnaires were analyzed using SPSS (Statistical Package for social Sciences) Version 21.0 .This statistical procedures was used to produce frequencies, percentages and graphs for the quantities of data collected from the physically handicapped and non-handicapped. However, distribution tables were used to relate responses to the set questions. The responses were collated thematically and along the objectives and questions. Narrative reports from group discussions were used to analyze the qualitative data. The researcher also presented quotes as given by various respondents so that he describes the situation as it occurred in its natural setting.

\section{Results and Discussion}

This section is about the biographical information of the participants in this study. The demographic information includes those of gender of respondents, age group of respondents, and marital status of the respondents.

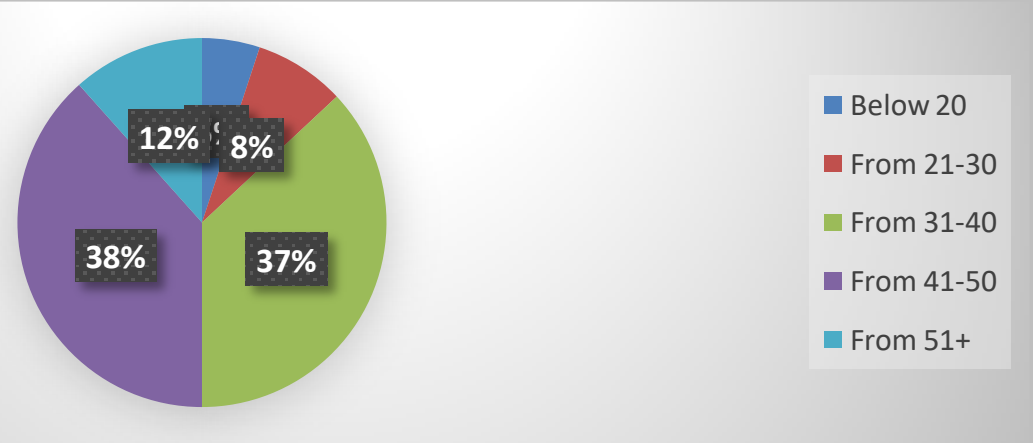

Figure 4. 1 : Age of the respondents 
Source: Primary data, (2020)

The above figure shows the distribution of respondents by their age. Majority of the respondents were found to be adults with $38.4 \%$ of the respondents in the age of 41 to 50 years and the second group of the respondents to be adults. Youth people also participated in this study with the percentage of $8.0 \%$ of them with the age ranging from 21 to 30 years. The implication of this is that disable people with advanced age have higher experience on how they have been treated for a long time and the information they can give coherent information. Another reason is that those people are in active years and they needs to be supported for being self- reliant.

\section{General information related to disability}

This section is about information related to disability status among participants in this study. The information that was collected at this point included kind of impairment, longevity of impairment, and causes of impairment.

Table 4. 1 : Category of impairment among participants

\begin{tabular}{lrr}
\hline Responses & Frequency & Percent \\
\hline Physical/albinism & 60 & 43.5 \\
Hearing & 26 & 18.8 \\
Mental & 34 & 24.6 \\
Visual & 18 & 13.0 \\
Total & 138 & 100.0 \\
\hline
\end{tabular}

Source: Primary data, (2020)

Table 4.1 shows the distribution of respondents by their kind of impairment or disability. Majority of the respondents who have participated in this study were found to have physical disability or albinos with the percentage of $43.5 \%$ of the total respondents. The implication of this is that those people most of the time use to endure their status and perform some activities like ordinal people and those people are influential on this study. Those people may get all information related to job and national development programs. Due to other forms of job which need official recruitments people with hearing, mental, and visual disabilities is critical and impossible since they are can't perform as well.

Figure 4. 2 : Length of impairment

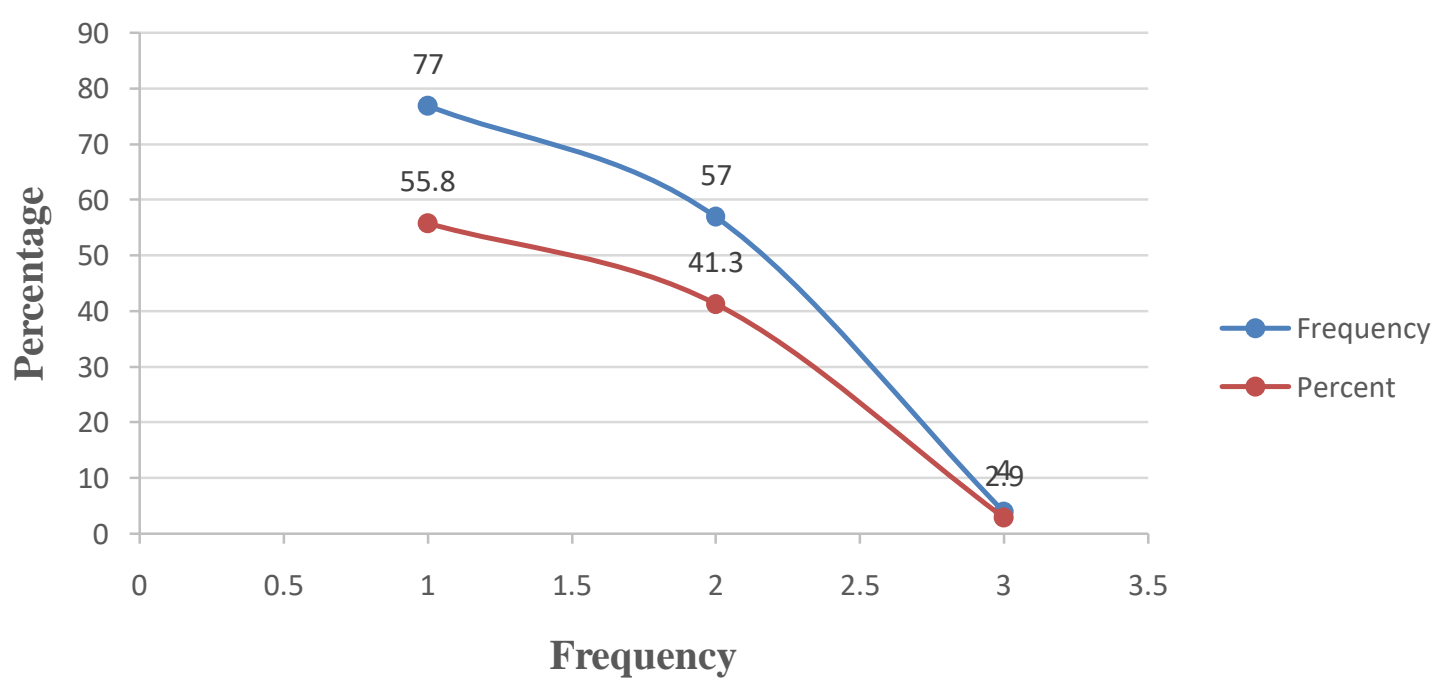

Source: Primary data, (2020)

Figure 4.2 shows the distribution of respondents by their longevity living with disability. Majority of the respondents who have participated in this study provided that they have born with their disability with the percentage of $55.8 \%$ of the total respondents who have participated in this study. Except the occurrence of the genocide against Tutsi in 1994 and liberation war of RPF that lead to big number of causalities in Rwanda there no other known disasters that can cause disabilities. Apart from those 2 factors that are said above most of people with disabilities are known to be in such conditions since their births. 
Table 4. 2 : Causes of handicap or disability

\begin{tabular}{lrr}
\hline Responses & Frequency & Percent \\
\hline War & 7 & 5.1 \\
Accident & 25 & 18.1 \\
Sorcery & 40 & 29.0 \\
Birth & 64 & 46.4 \\
Age & 2 & 1.4 \\
Total & 138 & 100.0 \\
\hline
\end{tabular}

Source: Primary data, (2020)

Table 4.2 shows the distribution of the respondents by the causes of their disability. Majority of them revealed that they have born with disability with the percentage of $46.4 \%$ of the total respondents who have participated in this study. This corresponds to the results on the longevity of disability among respondents where many of them revealed that the longevity of their disability started at their birth day. Sorcery also can be the cause of disability since people may rely on the archaic beliefs and they use to get modern medicine in late and at time medical services were expensive and simple illness could expose people to unexpected disabilities in various forms.

Table 4. 3 : Correlations between special needs education needs and socio-economic development.

Relationship between special needs education programs and welfare of people with disabilities in Huye District.

The third specific objective of this study was to assess the relationship between special needs education and socio-economic development of disabled people in Huye District. This was achieved by using correlation mechanism where positive value of it assumes the positive relationship and vice versa. The significance of the relationship is tested using the significance level of 0.05 where the tabulated pvalue less than it indicate the significance of the relationship and vice versa.
Inclusive education

Mainstreaming

Enrichment
Pearson Correlation

Sig. (2-tailed)

$\mathrm{N}$

Pearson Correlation

Sig. (2-tailed)

$\mathrm{N}$

Pearson Correlation

Sig. (2-tailed)

$\mathrm{N}$ development

*. Correlation is significant at the 0.05 level (2-tailed).

Note: $r_{s}=1$ : Perfect Correlation, $0.9 \leq r_{s}<1$ : Strong Correlation (very high ), $0.7 \leq r_{s}<0.9$ : High Correlation, $0.5 \leq r_{s}<0.7$ :Moderate Correlation, $r_{s}<0.5$ :Weak (low) Correlation, $r_{s}=0$ : Absence of Correlation(Saunders, 2003)

\section{Inclusive education and Socio-economic development}

According to table 4.3 inclusive education is lowly positively related to socio-economic development of disabled but this was found to be not statistically significant since the $\mathrm{r}=.034$ and the $\mathrm{p}=.692$ since it is greater than 0.05 which was taken as the significance level.

Mainstreaming and Socio-economic development It has been found that there is positive correlation between all indicators of special needs education but the significance relationship was found between mainstreaming and socio-economic development of disabled people considering $\left(\mathrm{r}=.181^{*}, \mathrm{P}=.033\right)$. This happened since the (r) meaning correlation is positive and the tabulated $\mathrm{p}$ is less than 0.05 .
Mainstreaming here is seen as important in special need education since it helps to know exactly what is needed for disabled people.

Enrichment and Socio-economic development According to Table 4.3 inclusive enrichment is lowly positively related to socio-economic development of disabled but this was found to be not statistically significant since the $\mathrm{r}=$. 088and the $\mathrm{p}=.307$ since it is greater than 0.05 which was taken as the significance level.

\section{Conclusions}

It was revealed that found that there is positive correlation between all indicators of special needs education but the significance relationship was found between mainstreaming and socio-economic 
development of disabled people considering ( $\mathrm{r}=$ $.181 *, \mathrm{P}=.033)$.

\section{Acknowledgments}

I wish to acknowledge Dr. Hesbon Opio Andala and Mr. Harerimana Jean Paul for their contribution to this work from the beginning up to it's the completion. I need to extend my acknowledgement to the Mount Kenya University, HUYE District authorities for their support and collaborative in term of data collection

\section{Reference}

[1] Adams, D., \& Tiesdell, S. (2012). Shaping places: Urban planning design and development.New York, NY: Routledge.

[2] Bates (Eds.), International encyclopedia of the social and behavioral sciences(Vol. 6, pp.35873592). New York, NY: Elsevier.

[3] Bloom, D. E. (2007). Education, health, and development. Cambridge, MA: American Academy of Arts and Sciences.

[4] Bloom, D. E. (2007). Education, health, and development. Cambridge, MA: American Academy of Arts and Sciences.

[5] Brokensha, D. (2001). Development: Socialanthropological aspects. In N.J. Smelser \& P.B.

[6] Buenstorf, G. (Ed.). (2012). Evolution, organization, and economic behavior. Northampton, MA:Edward Elgar.

[7] Carissa, L (2015). "Advantages \& Disadvantages to Mainstreaming Special Education Children". The Classroom.com.

[8] Cibangu, K.S. (2016). The contribution of modernization theory to ICT4D's research. In H. Rahman (Ed.), Human development and interaction in the age of ubiquitous technology (pp. 1-24). Hershey, PA: IGI Global.

[9] Convinsky, K. E., Palmer R. M., Fortinsky, H. R., Counsell S.R., Stewart, A. L., Kresevic, D., Burant, C. J., and Landefeld C. S. (2003). Loss of Independence in Activities of Daily Living in Older Adults Hospitalized with Medical Illnesses: Increased Vulnerability with Age. JAGS 51:451-458, 2003

[10]Drimie, S., \& Casale, M. (2009). Multiple stressors in Southern Africa: the link between HIV/AIDS, food insecurity, poverty and children's vulnerability now and in the future. Aids Care, 21(S1), 28---33.

[11]Emerson, Eric, Ros Madden, Janet Robertson, et al. (2009). Intellectual and Physical Disability, Social Mobility, Social Inclusion \& Health.

[12] Filgueira, H.C. (2001). Social development. In N.J. Smelser \& P.B. Baltes, Internationalencyclopedia of the social and behavioral sciences (Vol. 6, pp. 3583-3587). New York, NY:Elsevier.

\section{ISSN 2455-6378}

[13] Giugale, M.M. (2014). Economic development: What everyone needs to know New York, NY: Oxford University Press.

[14] Groffen, Danielle, and Jacques van, (2008). Material deprivation and health---related dysfunction in older Dutch people: findings from the SMILE study. The European Journal of Public Health 18, no. 3: 258---263.

[15] Grundy, E. and Holt, G. (2001). The socioeconomic status of older adults.How should we measure it in studies of health inequalities? J Epidermal Community Health

[16] Guralnik M, and Eleanor M Simonsick. (1993).Physical disability in older Americans. Journal of Gerontology 48, no. Special Issue: 3-10.

[17] Hancock \& Pudney (2014). Assessing the distributional impact of reforms to disability benefits for older people in the UK. Implications of alternative measures of income and disability costs. Ageing and Society.

[18] Subramanian, L., \& Jones C. (2013). Understanding e-waste management indeveloping countries. Building sustainability in the Indian ICT sector. IDPM DevelopmentInformatics Working Paper No.52.

[19] IDEA Funding Coalition (2001), "IDEA Funding: Time for a New Approach," Mandatory Funding Proposal, Feb. 20 2001, p. 2.

[20] Jones, A., Jones, C. and Ndaruhutse, S. (2014). Higher Education and Developmental Leadership: The Case of Ghana. Developmental Leadership Program Research Paper 26.

[21] Kenneth, S. (2018)Mainstreaming Special Education Students: The Parent Role.

[22] Khattak \& Khan, J. (2012). The Contribution of Education to Economic Growth. Evidence from Pakistan. International Journal of Business and Social Science, 3(4), 145-151

[23]Link, B. G \& Kelsey J. L, (1988). The measurement of social class in epidemiology.

[24] Matthew L. (2018) Inclusion vs. Mainstreaming. What You Need to Know Before Putting Your Child in a Classroom Program

[25] Moffatt, P. (2013). Econometric Methods. Autumn Term, 2013 Lecture notes. Norwich University of East Anglia

[26] Carlson, J. E., Black, S. A, Goodwin, J. S., \& Markides, K. S. (1999). Disability in older adults. Prevalence, causes, and consequences. Behavioral Medicine.

[27] Partridge C., Johnston, M., and Morris, L. (1996): Disability and health: perceptions of a sample elderly people. 1996, 1:17-29.

[28] Perry, C.D. (2001). Infrastructure investment. In N.J. Smelter and P.B. Baltes, Internationalencyclopedia of the social and behavioral sciences(Vol. 11, pp. 7486-7489). New York, NY:Elsevier. 
[29] Pope A., Tarlov, A. (1991): Disability in America: Towards a National Agenda for Prevention. Washington DC: Institute of Medicine, National Academy Press

[30] Russell, S. (2004). The economic burden of illness for households in developing countries: a review of studies focusing on malaria, tuberculosis, and human immunodeficiency virus/acquired immunodeficiency syndrome. The American journal of tropical medicine and hygiene 71 , no. 2 supply: $147---155$.

[31] Sen, K.A. (1988). The concept of development. In H.B. Cheery\& T.N. Srinivasan (Eds.),Handbook of development economics (Vol. 1, pp. 9-26). Oxford, UK: Elsevier.

[32] Sindelar and Deo J (1978), the Effectiveness of Resource Programming,Spec Educ.1978; 12: 1728
[33] Swartz, K., Miake, N., \& Farag, N. 2012. Long--term care: Common issues and unknowns. Journal of Policy Analysis and Management, 31(1), 139---152.

[34] Verbrugge L M. (1990). The iceberg f disability. In Stahl SM, ed. 1990. The Legacy of Longevity. Sage 55---75

[35] Von Korff and Lin EHB. (1992): Disability and depression among high utilizers of health care. Arch Gen Psychiatry. 1992; 49:91---100

[36] Weil, N.D. (2012). Economic growth(3rd Ed.). New York, NY: Pearson.

[37] World Bank (2006): World Bank Development Report. Equity and Development. (Online) available at<World Development Report 2006> 